\title{
Intelektualny i emocjonalny charakter działań pisarskich w koncepcji Jana Rymarkiewicza
}

Maciej Wróblewski 


\section{Maciej Wróblewski}

\section{Intelektualny i emocjonalny charakter działań pisarskich w koncepcji Jana Rymarkiewicza}

$\mathrm{J}$

an Rymarkiewicz (1811-1889), XIX-wieczny filolog i wieloletni nauczyciel Gimnazjum Św. Marii Magdaleny w Poznaniu, jest autorem interesującego podręcznika Nauka prozy'. Przeznaczony był on do kształcenia, na poziomie szkoły średniej, umicjętności pisania różnych odmian prozy - współcześnie powiedzielibyśsmy: użytkowej oraz niefikcjonalnej². Uzasadniając cel powstania podręcznika, Rymarkiewicz w Przedmonie do niego napisał:

W szkolach coraz mocniej czuć się daje potrzeba książki, która by na wzór Nauki poezji obejmowala naukę prozy, tj. naukę dobrego i pięknego pisania mową ojczystą i niewiązaną̧3.

Powiedzmy, że owa „nauka dobrego i pięknego pisania” opierała się na gruntownej znajomości teorii prozy: wiedzy o stylu oraz genologii form prozaicznych ${ }^{+}$.

Pojawiające się na kartach Naıki prozy nazwiska twórców oświeceniowych poetyk normatywnych - Jana Śniadeckiego, Euzebiusza Słowackiego, Franciszka Ksawerego Dmochowskiego, Józefa Franciszka Królikowskiego, Stanislawa Kostki Potockiego i Leona Bo-

\footnotetext{
' Poszczególne wydania podrçczuika Rymarkicwicza (185̄5. 1863. 1868) różnily się tytulem: Vanka prozy: Nauka prozy', czyli stylisty'ka; Prozaika, czyli stylistyka prozy'. P'onadto autor w wydaniu II i III dodal czçść, która poświęcona zostala kwestion genologicznym prozy.

2 Za Malgorzatą Czermińska przyjmuję iz prozę niefikcjonalną tworzą: literatura faktu, dokumnentu osobiste-

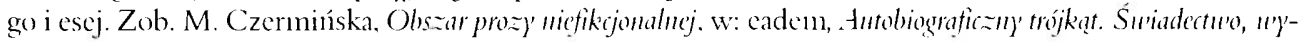

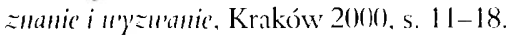

${ }^{3}$ J. Rymarkiewicz, Nanka proz)', op. cit., s. V.

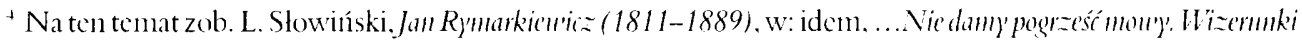
pedagogúu pozmaniskich XIX urick". Poznani 1982, s. 160)-181. Interesującą autoprezentacja Jana Rymarkicwicza

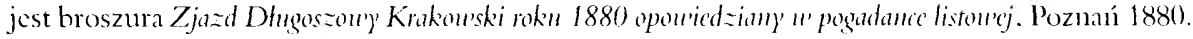


rowskiego - wskazıją na główne źródła inspiracji. O bliskim związku pracy Rymarkiewicza $z$ tradycją retoryczną świadczy również to, iż przy typologii form gatunkowych prozy odwolywal się ten XIX-wieczny filolog do renesansowej rozprawy Jakuba Górskiego ${ }^{5}$, autora lacińskiego dziela De generibus dicendi liber, adolescenti dicendi studioso opus et utile et necessarium".

Część stylistyczna omawianego tu podręcznika, zawarta w rozdziałach: O temacie, $c z$ ylizadaniu; Odyspozycji, czyli o toku myśli; O elokucji, czyli o u'ystou'ieniu mysti; O rytmie, czyli o toku mou'y; O harmonii, $c z$ yli o dźn'ięczności mou'y, nie ulegala istotniejszym zmianom w dwóch kolejnych edycjach podręcznika. Odmiennie rzecz siç przedstawiała z problematyką genologiczną — autor poświęcat jej w następnych wydaniach coraz więcej miejsca, rozwiązując przy tej okazji probleny teoretycznoliterackie, dotyczące właściwości poszczególnych odmian rodzajowych i gatınkowych prozy. Podobnie jak w staropolskich traktatach o poezji ${ }^{7}$, tak i w podręczniku Rymarkiewicza gatınek funkcjonowal jako zespól dyrektyw zarówno czytelniczych, jak i tekstotwórczych. Swoistym uzupełnieniem owego wykładu były zestawione również przez tego samego autora Wzory prozy' na uszystkie jej rodzaje, stopnie i ksztatty ${ }^{8}$. Podręcznik ten spełniał rolę wypisów szkolnych, w których znajdowały się fragnenty tekstów prozaicznych sklasyfikowane według paradygmatu rodzajowo-gatunkowego. Przedstawia się on następująco:

- Proza opisowa i powieściowa

(opisy, wizerunki, obrazy, charaktery, pogadanki, gawędy, romanse);

- Proza rozumująca i naukowa, czyli dydaktyczna

(monografie, podobieństwo i charakterystyki rozumowe, dysertacje naukowe i obyczajowe);

- Proza pobudzająca i zniewalająca, czyli oratorska

(mowy akademickie i obrzędowe, mowy sądowe, mowy kościelne).

Każda z wyżej wymienionych rodzajowych odmian prozy opatrzona zostala w wypisach (ale tylko w pierwszym wydaniu) dodatkową informacją na temat stylı. Zdaniem Rymarkiewicza, prozę opisową i powieściową cechuje „prawdopodobieństwo i wytworność”, prozę rozumującą i naukową „techniczność i wytworność, natomiast prozę pobudzającą i zniewalającą „sztuka i wytwornośc”. Powtarzający się wyraz „wytworność” sugerowal czytelnikowi, iż przedstawione $w$ wypisach utwory prozaiczne należą do literatury w takim samym stopniu, co wymowa (krasomówstwo) i poezja. W swojej koncepcji nie odrzucał on zatem, przynaj-

"Na temat znaczenia koncepcji teoretycznoliterackich w XVI wicku jakuba Górskiego zob. A. Werpachow-

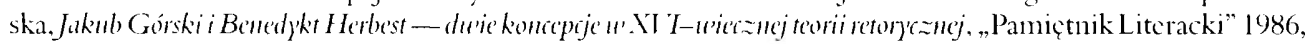
z. 1-2. s. 179-192.

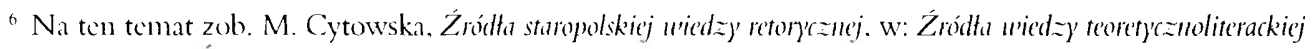
u' dan'ncj Polsce. Średniourietze - Re'nesuns - Barok. wst., wyb. i opr. M. Cytowska. T. Michalowska, Warszawa 1999, s. 59-65.

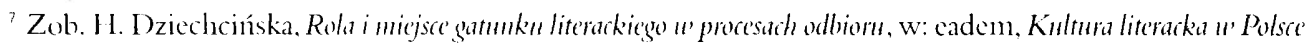

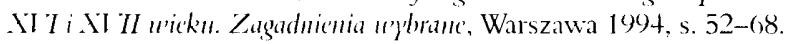

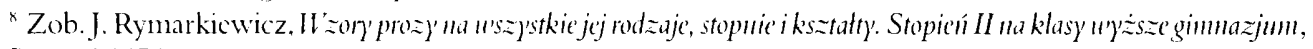
Poznań 1856. 
mniej w niektórych jej przykładach, ,poetyckiego”, czyli dziś byśmy powied zieli: literackiego opracowania strony językowo-stylistycznej, kompozycji oraz konstrukcji autora/podmiotu mówiącego. Znaczylo to, iz oddziaływanie wybranych utworów prozy na odbiorcę odbywalo się nie tylko droga "rozumową", jak to wówczas tłumaczono, ale także niemałą rolę w tym procesie odgrywała sfera emocjonalna.

Rymarkiewicz, wymieniając cechy obszaru prozatorskiego, wprost odwolal się, per analogiam, do dystrybucji zastosowanej przez I Iipolita Cegielskiego w Nance poezji (1845). Poszczególnym odmianom prozy odpowiadały, pod względem stylistycznym oraz kompozycyjnym, określone rodzaje poezji: prozie opisowej i opowiadającej - poezja opisowa, prozie naukowej i rozumowej - poezja liryczna, prozie oratorskiej — poezja dramatyczna". Również użyte przez Rymarkiewicza określenia wobec poszczególıych odmian prozy — „ozdobna”, „krasomówcza” oraz „piękna” - określające to, czym ona może być, przypominają szeregi przymiotników odnoszone do właściwości poezji — z tą różnicą, że wobec tej ostatniej stosowano tryb bezwarunkowy, a wobec prozy warunkowy.

Proza ze wszystkimi swoimi odmianami ujętymi w przedstawianej przez Rynarkiewicza systematyce włączona zostala do literatury, ale ta jej przynależność zależała od stylistycznego oraz treściowego opracowania ${ }^{1 "}$. Wśród gatunków prozaicznych znalazly się, poza obowiązkowo zaliczanym tam krasomówstwem, następujące formy:

- Proza historyczna

— powiastki i obrazki;

- klechdy, skazki, baśnie;

- gawędy, pogadanki, pamiątki;

- legendy, czyli podania święte:

- powieści, obrazy, romanse;

- podróze, pamiętniki;

- biografie, czyli żywoty historyczne;

- monografie, czyli ustępy historyczne;

- synteza, system albo organizm historii.

- Proza dydaktyczna

- adagia, sentencje, czyli przyslowia i zdania moralne;

- anegdoty, koncepty, czyli fraszki, dowcipy;

- apologi, czyli bajki i powiastki moralne;

- alegorie, parabole, czyli podobicństwa, przypowieści;

- charakterystyki, czyli wizerunki;

- dysertacje, czyli rozprawy;

- rozbiory, czyli krytyki;

- monografie umiejętne, dziela naukowe:

"Zob. idem, Namka prozy', azyli stylistyka. Poznań 1863. s. 196-198.

10 Zob. K. Bartoszyniski, Poureśs "usuretle literackości, Warszawa 1901. s. 267. 
- systemata umiętności".

Biorąc pod uwagę wymienione gatunki, należy stwierdzić, iż Rymarkiewicz oddzielił prozę o właściwościach estetycznych, którą cechowała, jak już wcześniej powiedziano, „wytworność”, od jej odmiany pospolitej, gdzie można bylo znaleźć pisma „powszechne”, ,urzędowe" i „sprawunkowe" "2. Zastanówmy siç przez clıwilę, co było przyczyną takiego whaśnie postępowania.

Zgodnie z tradycją oświeceniową Rymarkiewicz zaliczyl prozę krasomówczą do literatury na równych prawach z poezją. Podobnie uczynił z prozą filozoficzną oraz historyczną o retorycznym rodowodzie. Problem pojawił się wówczas, gdy należało „wygospodarować” w systematyce miejsce dla takich form, jak diariusz, pamiętnik, (auto)biografia oraz szkic historyczny, krytycznoliteracki, filozoficzny. Wymienione gatunki nie zostały uwzględnione (poza biografią) w oświeceniowych podręcznikach nauki stylu i wymowy, na przyklad Józefa F. Królikowskiego, Tomasza Szumskiego i Euzebiusza Słowackiego. Dlatego też Rymarkiewicz, chcąc je wlączyć do prozy, która dotychızas skladała się tylko z form o proweniencji retorycznej, musial dokonać w swojej systematyce wyraźnego podziału na „prozę pospolitą” i .prozę piękną”. Taki właśnie sposób postępowania pozwolił na nowo określić to, czym nauka prozy (dawna teoria wymowy i stylu) powimna byla się zająć. A zatem pamiętnik, diariusz, autobiografia, szkic w swoich licznych odmianach znalazly się w obszarze zainteresowania „prozaiki”. Owe odmiany z retoryczną prozą lączyly forma zapisu i cechy językowo-stylistyczne, natomiast wlaściwości kompozycyjne oraz opracowanie tematyki świadczyły o ich odrębności. Antycypując rozważania, powiedzmy, że nosily one pewne cechy przynależne poezji; według Rymarkiewicza oddziaływały zatem na uczucia odbiorcy, a nie tylko na jego intelekt.

Posługiwanie się „prozą piękną” wymagało od przyszłego adepta sztuki literackiej, zdaniem Rymarkiewicza, określonych umiejętności. W tym stwierdzeniu kryło się przekonanie autora, że gromadzona w ramach ksztalcenia literackiego ${ }^{13}$ wiedza retoryczna determinowala sprawność posługiwania się złożonymi formami wypowiedzi. Jeśli uzmysłowimy sobie czas (druga polowa XIX wieku), to fakt gromadzenia, a potem funkcjonalnego korzystania z tej wiedzy czynił jej glówny przedmiot - prozę - szczególnie wartościowym ${ }^{1+}$. Ilatego też, aby pisanie pamiętnika czy szkicu historycznego uczynić godnym miana sztuki, należało, przypomnijmy, przeprowadzić gradację w obszarze samej prozy, która powszechnie kojarzona była wówczas z tekstem pospolitym i użytkowym. Oczywiście, walorem prozy, z wy-

${ }^{11}$ J. Rymarkiewicz, Prozaika, op. cit., s. 218.

12 Ibidem, s. 3.

${ }^{13}$ XIX-wieczne ksztalcenic literackic obejmowalo edukację polonistyczną. ale także naukę jçzyków klasycznych - greki i laciny - oraz języków zachodnich. Zob. W. Dynak, Kanon sj'mboliki narodon'ej ispoteczncj w'gali-

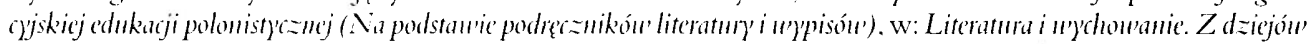
edukacji literackicj " Galicji. red. M. Inglot. Wroctaw 1983 (Acta Universitatis Whatislaviensis 633), s. 35-49.

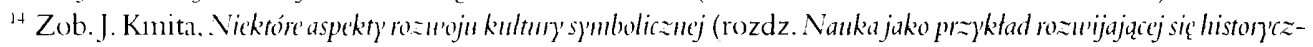
mie dzicdzin) kultur' symbolic zmej), w: idem. O kultmze' symbolicznej. Warszawa 1982, s. 106-117. 
jątkiem krasomówstwa, jest to, że oddziałuje ona na intelekt i tą drogą następuje jej percepcja. Ale czy znaczyło to jednocześnie, że Rymarkiewicz pozbawił ten obszar aspektu uczuciowego i emocjonalnego, gdy chodziło o kwestie odbioru? Pytanie to należy postawić, mając na uwadze przede wszystkim utwory pamiętnikarskie, diarystyczne i epistolarne.

Bardzo istotne jest to, że Rymarkiewicz, w przeciwieństwie do swoich „mistrzów”, zrównał gatunki należące pierwotnie do wymowy (kazania, mowy wojenne) z „dziejopisarstwem” i „naukopisarstwem":

Albowiem, gdyby zawierała w sobie [scil. retoryka] samo tylko krasomówstwo, jak zwykle rozumiemy, nie obejmowalaby natenczas dziejopisarstwa ani naukopisarstwa, które przecież takąż samą wymownością się zalecają jak krasomówstwo ${ }^{15}$.

Fakt ten jest not'mm w stosunku do rozwiązań proponowanych przez poetyki oświeceniowe. Owo przesunięcie terminologiczne sprawilo, że różnica między prozą (historyczną i naukową) a krasomówstwem, jeśli nie została jeszcze calkowicie zniesiona, to dążył Rymarkiewicz do ich przybliżenia, nie wyłączając rzecz jasna pamiętnika czy diariusza. Obydwa obszary w równym stopniu mogly odznaczać się pięknym stylem, jasnością logicznego wywodu czy silą argumentacji. Świadczyła o tym dobitnie ówczesna praktyka pisarska; coraz częściej w literaturze dokumentu osobistego i literaturze faktu, wychodzących spod pióra pisarzy drugiej połowy XIX wieku, dostrzegano wartości estetyczne, które dotąd przypisywano jedynie obszarowi poezji1 $1^{16}$. Fakt ten w pewnym stopniu uwzględnil Rymarkiewicz, pisząc:

Skoro więc proza w tylu punktach i względach ma styczność i powinowactwo z poezją, skoro utwory jej, jako dzieła wiekopomne w literaturze w równym rzędzie stają z dzicłami poezji (... ${ }^{17}$.

W tym ostatnim stwierdzeniu ukryty jest klucz, pozwalający zrozumieć postçpowanie Rymarkiewicza - zdawałoby się wiernego kontynuatora sztuki retorycznej. O ile teoretycy wymowy przede wszystkim dokonywali podziałów oraz wyznaczali granice w imię utrzymania porządku, o tyle autor Nauki prozy' szukał „porozumienia” między prozą a poezją, wskazywal na zależności między obydwoma obszarami, pozbywszy się najpierw balastu prozy „pospolitej".

W drugim i trzecim wydaniu swojego podręcznika Rymarkiewicz rozbudowal część, która zawierała podział form prozaicznych na rodzaje (.charakter”) i gatunki (.kształt indywidualny”). Okazało się jednak, że systematyka utworów prozaicznych budzila więcej wątpliwości niż gatunków poezji:

${ }^{15}$ J. Rymarkiewicz. Nanka proz)' op. cit.. s. 3.

16 Zob. W. Olcndzki, Felieton ifelietoniści, „Niwa“ 1875, t. VIII, s. 222-429; Litwos [H. Sicnkicwicz], Szkice Kilbali, .Niwa" 1880 , t. XVIII, z. 140, $1+1$.

${ }^{17}$ J. Rymarkicwicz, Nunka prozy. op. cit., s. $1+2$. 
Ksztalty, czyli typy utworów pisarskich w prozie mniej są wydatne niż ksztalty w poezji; dlatego też tu nie tak szczegółowo scharakteryzować się dadzą, jak to zwyklo bywać w poetyce ${ }^{18}$.

Jak z powyższego cytatu wynika, Rymarkiewicz przeczuwal, iż niektóre utwory prozaiczne nie poddają się jednoznacznej klasyfikacji — nie są ani w pełni "rozumowe”, ani też „uczuciowe". W tej kwestii wątpliwości budzila właśnic literatura paniętnikarska, diarystyczna, epistolarna (list romantyczny) i eseistyczna (szkic historyczny, filozoficzny, literacki), którą on uwzględnił. Jako spadkobierca i w pewnym stopniu kontynuator oświeceniowych teorii wymowy", korzystal przy ich opisie z antynomii ,proza - poezja”, "rozum - uczucie”, „prawda - fantazja”, co bylo krokiem metodologicznie ryzykownym.

Fikcja literacka (,fantazja”), choć była dostrzegana, to przecież obecność jej nie przesądzala o przynależności do poezji. Rymarkiewicz w tym wypadku mówił o wzajemnych związkach, a nawet ,splataniu” się niektórych gatunków z obszaru twórczości poetyckiej z prozaiczllymi:

Jak atoli w sztukach pięknych (...) częstokroć widzinny różne ich rodzaje z sobą pomieszane, tak i tu nierzadko się zdarza, iż znaniona służące właściwie poezji przenoszą się i wplatają do prozy, a na odwrót: cechy charakterystyczne prozy lączą się i splatają czasami ze znamionani poezji, do tego stopnia, iż trudno niekiedy rozpoznać wlaściwy pisarskiego tıtworu charakter ${ }^{21}$.

Pogląd o bliskości prozy i poezji dostrzec można również i w sposobie doboru przez Rymarkiewicza przykładów, które ilustrowały wybrany gatunek. Fragmenty utworów prozaicznych wskazane w podręczniku i zamieszczone w dołączonych do niego wypisach odznaczały się wysokimi walorami estetycznymi. W ten sposób dobrane ustępy prozaiczne mogly być postrzegane, jeśli brało się pod uwagę kwestie językowo-stylistyczne, jako bliskie poezji. Powinowactwo obu obszarów piśmiennictwa potwierdza jeszcze jeden przykład. Kwestia dotyczyła prozy historycznej.

Według Rymarkiewicza wypowiedź autora którejkolwiek z odmian prozy historycznej powinna ograniczyć się do prezentacji faktów

...z przezroczystą jasnością, z pelnią życia i z takim przejęciem, iż osobowość piszącego całkowicie znika ${ }^{21}$.

Mimo to autor Nauki prozy w dalszej części rozważań nie wahal się przed porównaniem pracy historyka do poety. Jego zdaniem obaj dążą do ujjęcia swojego materiału w spójną całość. Takie pojmowanie historii bardzicj przypomina literaturę piękną niż naukę, bowiem proces

Ix Ibidem, s. 222.

1" Zob. L. Slowiniski, op. cit., s. 175.

2" J. Rymarkiewicz. Nanka pro z)' op. cit., s. 12.

?t Ibidem, s. 252. 
zespalania poszczególnych faktów historycznych odbywa się analogicznie do tworzenia narracji literackiej:

Konsekwencją tego [scil. szkoły erudytów] byl kryzys dziejopisarstwa; okazało się ono pozbawione zasad umożliwiających selekcjç i hierarchizację materiału, a tym samym takie jego uporządkowanie, jakie pozwala uczynić z dzieła historycznego utwór literacki, nie przez wprowadzenie doń fikcji, lecz przez ustanowienie w nim porządku zorganizowanego wokół jakiejś idei, której wszystkie przedstawione zdarzenia są podporządkowane ${ }^{22}$.

Wśród autorów reprezentujących tę część prozy Rymarkiewicz wymienil Marcina Bielskiego, Stanistawa Orzechowskiego, ale i Joachima Lelewela, Maurycego Mochnackiego i Karola Szajnochę.

Reasumując, podręcznik Rymarkiewicza - Nauka prozy' - wyrastał z oświeceniowych koncepcji retorycznych, gdzie obowiązywat dychotomiczny podział literatury na poezję i prozę. Poznański filolog postąpil jednak o krok dalej, whączając do swojego podręcznika także te formy, które ze względu na cechy językowo-stylistyczne i kompozycyjne nie mieścily się już w tradycyjnie pojmowanym obszarze prozy. Paniętnik czy szkic postrzegane byly przez Rymarkiewicza jako utwory łączące w sobie pewne cechy poetyckie i prozaiczne, a zatem ich odbiór następował zarówno droga ..rozumową", jak i emocjonalną.

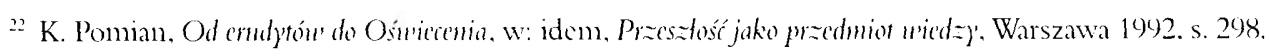

